\title{
Questão ética, controle e regulamentação da informação no webjornalismo colaborativo
}

Augusto de Freitas Lohmann, André Soares Monat

\begin{abstract}
Resumo
Introdução: 0 artigo aborda a questão ética na Internet, com enfoque na colaboração de leitores em sites noticiosos. A análise abrange o impacto da inclusão do conteúdo colaborativo no âmbito jornalístico, e apresenta questionamentos a respeito da relevância desse tipo de conteúdo, bem como formas de integrá-lo ao conteúdo noticioso convencional. Método: Estudo bibliográfico envolvendo um levantamento de referenciais sobre a questão da colaboração de leitores em sites de jornalismo; os impactos da inclusão dessas práticas colaborativas para o jornalismo convencional; bem como das possibilidades de controle e moderação da informação enviada pelos leitores de maneira a validar sua veracidade. Resultados: Foram encontrados referenciais teóricos apontando para as vantagens e desvantagens do uso da informação colaborativa nos sites noticiosos, bem como diferentes mecanismos para integração e controle dessa informação, dentre elas a prémoderação, a meta-moderação e a moderação automática feita por algoritmos de inteligência artificial. Conclusões: A solução ideal, ainda não encontrada, passa necessariamente por esse questionamento a respeito da forma com que a participação do leitor deve ser aproveitada pelos jornais e oferecida para o público geral. Essa é uma discussão que esbarra em muitos momentos com a questão ética que permeia a prática jornalística em toda sua história, e é sem dúvida um dos grandes desafios que as empresas jornalisticas terão que enfrentar nos próximos anos.
\end{abstract}

\section{Palavras-chave}

Colaboração em redes sociais. Webjornalismo. Moderação da informaação. Ética no Jornalismo.

\section{Introdução}

Verdade, ética e isenção na apuração dos fatos no processo de composição do conteúdo noticioso são conceitos inerentes a prática do jornalismo. $\mathrm{O}$ texto abaixo faz parte do juramento do jornalista, recitado no momento em que o então estudante de jornalismo se torna oficialmente um profissional da área.

Juro / exercer a função de jornalista / assumindo o compromisso / com a verdade e a informação. / Atuarei dentro dos princípios universais/ de justiça e democracia,/ garantindo principalmente / o direito do cidadão à informação. / Buscarei o aprimoramento / das relações humanas e sociais,/ através da crítica e análise da sociedade, / visando um futuro / mais digno e mais justo / para todos os cidadãos brasileiros.

A partir deste juramento, o agora jornalista se compromete a oferecer à sociedade apenas a verdade dos fatos e a informação pura e isenta. Nos manuais de jornalismo dos principais veículos noticiosos do país, textos parecidos com esse são apresentados como modelo de comportamento padrão a ser seguido pelos profissionais da área. No Código de Ética, aprovado em 1987 no Congresso Nacional dos Jornalistas, o Artigo $7^{\circ}$ estabelece que "O compromisso fundamental do jornalista é com a verdade dos fatos, e seu trabalho se pauta pela precisa apuração dos acontecimentos e sua correta divulgação." (BARBEIRO; LIMA, 2002)

O mesmo conceito é apresentado no trecho abaixo, atribuindo de certo modo um tom de "romantismo" ao ideal de ética e verdade que é esperado de um profissional do jornalismo:

A função social do jornalismo está intimamente atrelada à visão romântica lançada sobre a identidade do profissional que é assim identificada por Bill Kovach e Tom Rosentiel: 
1. A primeira obrigação do jornalismo é a verdade.

2. Sua primeira lealdade é com os cidadãos.

3. Sua essência é a disciplina da verificação.

4. Seus profissionais devem ser independentes dos acontecimentos e das pessoas sobre as que informam.

5. Deve servir como um vigilante independente do poder.

6. Deve outorgar um lugar de respeito às críticas públicas e ao compromisso.

7. Tem de se esforçar para transformar o importante em algo interessante e oportuno.

8. Deve acompanhar as notícias tanto de forma exaustiva como proporcionada.

9. Seus profissionais devem ter direito de exercer o que lhes diz a consciência (2003).

Essa lista de conduta do profissional de imprensa aponta para o jornalismo como atividade objetiva, objetividade esta que cobrará responsabilidade social do jornalista (BRAMBILLA, 2006).

Dessa forma, o que se observa é que o conceito de "verdade" é apresentado como algo tangível e possível de ser alcançado, o que por si só provoca discussões não somente no campo do jornalismo, mas em áreas como a filosofia ou a psicologia. O trecho a seguir, presente no Manual de Redação do jornal "O Globo", ajuda a ilustrar o que a instituição jornalística espera de seus profissionais:

O repórter é um curioso movido permanentemente pelo desejo de saber o que acontece e de entender porque aconteceu. Se não for assim está na profissão errada. E não basta querer saber: é preciso saber tudo, e ter a obstinação de saber certo (GARCIA, 1992, p. 11).

A notícia jornalística, entretanto, nada mais é do que o resultado do relato de um fato, e o conceito de notícia como "verdade absoluta" se mostra utópico à medida que o ideal de isenção se apresenta como inviável não somente no jornalismo, mas em qualquer atividade humana. Pode-se entender então que o conteúdo jornalístico, mesmo se produzido por jornalistas profissionais, não pode ser encaixado em um modelo idealizado de "verdade absoluta", mas apenas visto como uma versão da verdade, um recorte de uma determinada situação sob uma ótica específica. Da mesma forma, por se tratar de um relato, o jornalista se apresenta como um intermediário entre o fato e o leitor, e nesse papel sua simples presença torna esse relato uma visão interpretativa do fato, influenciada por questões culturais, sociais, ideológicas, profissionais etc. Apesar da impossibilidade de um relato verdadeiramente imparcial, os jornais tendem a ser identificados - por significativa parcela de seus leitores - como instrumentos de descrição da realidade de maneira plena e absoluta o que, a priori, concede status de verdade a seu conteúdo.

No livro "Os elementos do Jornalismo" é abordada a dificuldade dos jornalistas em compreender e trabalhar com o conceito de verdade:

[...] os próprios jornalistas nunca tiveram uma noção clara do que querem dizer com veracidade. Por sua própria natureza, o jornalismo é reativo e prático, não filosófico ou introspectivo. Não existe muita reflexão escrita dos jornalistas sobre esses assuntos, e o pouco que existe não é lido pela maioria dos profissionais do ramo. As teorias do jornalismo ficam nas cabeças dos acadêmicos, e grande parte dos jornalistas sempre desvalorizou o ensino profissional (KOVACH; ROSENTIEL, 2003, p. 66).

O objetivo deste artigo não é o de se aprofundar no estudo de definições de ética e moral, ou dos diferentes conceitos de verdade, temas amplamente estudados por diversos ramos da filosofia e da psicologia. A ideia é apontar para a existência do problema e entender o momento atual da questão ética e do ideal de verdade dentro da produção de conteúdo jornalístico, com ênfase no viés da entrada de conceitos do chamado "jornalismo colaborativo" nas grandes empresas jornalísticas (com a participação ativa de usuários e de "não jornalistas" no processo de construção da narrativa noticiosa). Cada vez mais se torna urgente a discussão sobre o que é ou não "ético" na utilização de conteúdos gerados coletivamente por "amadores" no âmbito dos sites noticiosos.

Como abordagem metodológica, foram levantados referenciais teóricos a respeito da temática do jornalismo colaborativo na web, da incorporação 
de conteúdo produzido por usuários em sites de empresas noticiosas, bem como dos mecanismos de controle e regulamentação desse tipo de conteúdo. Procurou-se identificar posições favoráveis e contrárias aos modelos de jornalismo colaborativo atualmente utilizados nos principais sites de notícias, e a participação de usuários na construção do processo noticioso. Dessa maneira, tornou-se possível aprofundar o entendimento sobre a questão a partir da junção de diferentes visões sobre a melhor abordagem para a questão ética e o aproveitamento da informação colaborativa em sites de notícias.

\section{Jornalismo colaborativo e o "efeito de real"}

A dificuldade de alcançar um ideal de verdade se torna ainda mais evidente com o surgimento e a consequente popularização do jornalismo online ou digital, onde o imediatismo e a necessidade da informação em "tempo real" - no momento do acontecimento - torna a prática do jornalismo ainda mais reativa, e nesse contexto há cada vez menos espaço para a verificação eficiente dos dados. Apesar disso, para Dalmonte (2009), as características do jornalismo na Web ajudam a estabelecer o que ele chama de "efeito de real".

Por meio das estratégias concernentes à apresentação de notícias em tempo real, o Webjornalismo propõe uma estrutura narrativa que busca ser portadora da realidade. Além dos recursos para promover o efeito de real, a inovação fica a cargo do desejo de apagamento da membrana que se coloca entre o fato e a notícia, que distingue a realidade e sua representação. Como plataforma na qual se inscreve a cena midiática, o Webjornal oferece inúmeros recursos por meio dos quais a realidade é apresentada, por vezes, em sequências sem edição, como nos vídeos disponibilizados.

Cria-se a sensação de que o portal Web jornalístico tem uma redução de filtros que, numa situação de porosidade, permitem a passagem do acontecimento à categoria de notícia. Em comparação a estruturas rígidas de grades de horário que restringem a apresentação do material jornalísti- co, como no rádio e televisão, (embora havendo espaço para plantões), ou no impresso, a notícia na $W e b$ não tem restrição temporal, podendo ser disponibilizada e acessada a qualquer instante (DALMONTE, 2009, p. 202).

É importante ressaltar que essa sensação de realidade não se traduz necessariamente em uma verdade, em uma representação fiel da realidade. O imediatismo e a consequente verificação menos apurada dos fatos evidentemente não contribuem para que o jornalismo online seja uma fonte de notícias mais verdadeira do que outras formas de jornalismo tradicional, de maneira que é preciso cuidado para evitar que essa sensação se traduza em um processo enganoso para o leitor.

A entrada de seções de jornalismo colaborativo nos sites de grandes empresas jornalísticas contribuiu para a ampliação tanto do "efeito do real" quanto do perigo envolvido nessa maior sensação de realidade. A abertura do espaço noticioso para a participação dos leitores faz com que se revelem novos pontos de vista sobre uma determinada situação. Dessa forma, em tese, quanto mais colaboradores enviarem relatos e opiniões a respeito de um determinado assunto, mais próximo o leitor estará da realidade, em seu caráter ideal. $\mathrm{O}$ relato do jornalista profissional passaria a ser apenas mais um relato, mesmo que atribuído de uma carga maior de importância, e a composição de conteúdos noticiosos torna-se algo polifônico, como aponta Dalmonte:

A efetiva participação do leitor, ou a possibilidade de participação, desempenham importante papel para o desenvolvimento do efeito de real, pois as notícias não estão distantes, dispersas no mundo virtual. Ao interagir com um produto jornalísti$\mathrm{co}$, o leitor agrega àquela peça informativa não apenas suas impressões, mas seus dados pessoais. O recurso jornalístico e o uso de personagens é ampliado, pois além das fontes selecionadas para a composição do texto, outras vozes são agregadas, fazendo que a matéria se torne mais polifônica. Sob a perspectiva de diversos olhares, vai além da instância de produção (DALMONTE, 2009, p. 193). 
Em situações onde a colaboração do leitor não é assumidamente opinativa, mas ganha o tom de relato de uma situação vivenciada pelo mesmo, na forma de um testemunho ocular, a sensação de realidade torna-se ainda mais evidente. Nesse sentido, para Dalmonte (2009, p. 213),

[a] concepção de que o discurso jornalístico representa o real é ampliada, pois se cria a ideia de que aquele discurso é o real, relatado com características testemunhais.

Entretanto, em um ambiente como o da Internet, um baixo nível de controle da informação enviada sob a forma de colaboração, aliada a sensação de real, pode se traduzir em um resultado perigoso. Andrew Keen cita, em seu livro, a opinião de um jornalista da The New Yorker que questiona seriamente a publicação por parte dos grandes jornais de conteúdos enviados por leitores, muitas vezes anônimos, sem o devido controle das informações publicadas.

Lemann, da The New Yorker, salienta que "a sociedade cria estruturas de autoridade para produzir e distribuir conhecimento, informação e opinião". Para quê? Para que saibamos que podemos confiar naquilo que lemos. Quando um artigo se apresenta sob a bandeira de um jornal respeitado, sabemos que foi examinado por uma equipe de editores tarimbados e com anos de aprendizado, confiado a um repórter qualificado, pesquisado, verificado, editado revisto e apoiado por uma organização de notícias fidedigna que dá testemunho de sua veracidade e precisão. Se esses filtros desaparecem, nós, o público geral, ficamos diante da tarefa impossível de esquadrinhar e avaliar um mar interminável de conjecturas confusas de amadores (KEEN, 2009, p. 54).

A partir, portanto, dessa implementação de modelos de jornalismo colaborativo ao contexto dos grandes jornais e sites noticiosos - cujos espaços para a participação do leitor são ampliados de maneira exponencial - a discussão é direcionada para um patamar onde as próprias empresas jornalísticas divergem quanto ao aproveitamento e ao controle das informações fornecidas por colaboradores, justamente em busca da melhor maneira de tratar a questão da sensação de real versus a publicação de informações sem a devida verificação. Ao mesmo tempo em que um testemunho enviado por um colaborador bem intencionado pode ser bastante elucidativo e informativo, um relato propositalmente tendencioso ou falso por parte de um usuário pode trazer prejuízos para o público leitor ou mesmo para a reputação do jornal. Mesmo um usuário bem intencionado poderia, por não ter a formação jornalística, e por influência das diversas questões apontadas no início deste artigo ou, ainda, pela própria impossibilidade humana de atingir a isenção, relatar um fato que lhe parecesse ser verdadeiro, mas na prática ser uma interpretação equivocada ou incompleta de uma situação. Em todos esses casos, fica evidente a necessidade das empresas noticiosas ampliarem a discussão a respeito da questão ética envolvendo a publicação de conteúdo colaborativo.

\section{O usuário como emissor de conteúdo: profissional versus amador}

Não obstante todas as divergências que envolvem a conceituação de ética dentro do campo do jornalismo "tradicional", o jornalismo colaborativo concede um viés de complexidade com a inserção de um novo ingrediente: o leitor que se transforma em usuário/jornalista. $\mathrm{O}$ processo usual da comunicação envolvendo um emissor (o jornal) e o receptor (o leitor) é inteiramente modificado quando essas duas figuras deixam de ser claramente distintas, e o receptor pode, ao mesmo tempo, exercer o papel de emissor da informação. Sobre esse novo momento do jornalismo e das relações midiáticas, Lemos (2009) aponta a liberação do pólo emissor e a conectividade em rede como fatores que propiciaram esse ambiente de reformulação do modelo de produção e consumo de conteúdo:

[...] a sociedade da informação passa por uma fase em que novos parâmetros estão começando a ser estabelecidos. A liberação do pólo emissor trouxe de volta (e ampliou) a conversação através de redes complexas, e possibilitou que mídias de funções pós-massivas ganhassem espaço: blogs dão furos, pessoas dão notícias em primeira mão através de redes sociais, como o Twitter. Pessoas "comuns" produzem conteúdo - con- 
forme o modelo read and write. Neste contexto, informações relacionadas a localidades, bastante específicas, denominadas "hiperlocais", ganham maior relevância. Esta importância se dá pelo fato de que, geralmente, elas são produzidas exatamente por quem não é jornalista e, tradicionalmente, fazia parte do público ao qual os meios de comunicação se dirigiam. O jornalismo caminha para uma nova fase (LEMOS, 2009, p. 2).

A partir do momento em que um novo elemento se faz presente na lógica jornalística como produtor de conteúdo, o site noticioso enfrenta a possibilidade da perda de sua unidade editorial. $O$ fato se torna ainda mais complexo quando se observa que esse novo elemento não está necessariamente imbuído dos conceitos de ética e de verdade que, em teoria, regem a atividade do jornalista profissional desde a formação acadêmica, passando pelos manuais de jornalismo difundidos nas grandes empresas jornalísticas.

A partir daí, algumas questões importantes se colocam: até que ponto um conteúdo conceitualmente distinto da visão da instituição jornalística e da ética profissional do jornalista pode ser inserido e implementado no produto final (no caso, o site noticioso)? De que forma esse conteúdo pode agregar valor ao produto sem que isso de alguma maneira se configure em possíveis consequências negativas para a instituição ou mesmo para o público leitor do jornal? A utilização de conteúdo gerado por não profissionais da área, sem a devida remuneração e sem vínculo institucional, fere a ética profissional? Indo mais além, conteúdos gerados por não jornalistas se enquadram verdadeiramente na categoria de "jornalismo"?

Dan Gillmor, autor do livro "We the Media: Grassroots Journalism by the People, for the People", defende a ideia de que o conteúdo gerado por indivíduos sem formação jornalística pode ser considerado jornalismo:

"Se isso é jornalismo? Eu diria que sim; é uma conversa, sem dúvida, mas é uma síntese coletiva do que as pessoas sabem, e quando alguém posta alguma coisa que não é verdade, outras pessoas pulam em cima e dizem, bem, isso está errado". Gillmor diz ainda que "O noticiário deveria ser uma conversa entre cidadãos comuns e não uma preleção que devemos aceitar cegamente como verdadeira (GILLMOR, 2004, p. 62).

Dalmonte reafirma esse discurso, corroborando a ideia de um jornalismo permeado por conteúdo colaborativo e amplificando a importância da participação de leitores, enfatizando a ideia de sensação de "realidade" e de uma aproximação com o público leitor até mesmo superior ao da matéria jornalística tradicional.

A palavra não é simplesmente aberta ao leitor, mas o fato de ele ter a chance de manifestar seja sua opinião, seja relatar o que acontece de relevante, passa a constituinte do próprio discurso da mídia. Enquanto discurso autorreferente, ao ressaltar a abertura para as contribuições dos leitores, são ressaltadas as potencialidades que um site tem de mostrar a realidade, a partir dos testemunhos, impressões, opiniões, etc. A ampliação das formas de aproximação entre o real e sua representação permitem que o discurso jornalístico crie novas formas de inserção do cotidiano em seus relatos e, com isso, ao estender o sentido de realidade, aproxime-se ainda mais do universo dos leitores (DALMONTE, 2009, p. 13).

Já Keen apresenta uma visão diametralmente oposta, colocando em dúvida a validade de permitir que uma pessoa sem formação possa realizar o papel de um jornalista, e que isso possa verdadeiramente ser categorizado como "jornalismo":

A simples posse de um computador e de uma conexão com a internet não transforma uma pessoa num bom jornalista, assim como o acesso a uma cozinha não faz de ninguém um bom cozinheiro. Mas milhões de jornalistas amadores pensam que faz. De acordo com um estudo realizado em julho de 2006 pelo Pew Internet and American Life Project, 34\% dos 12 milhões de blogueiros nos Estados Unidos consideram que seu "trabalho" online é uma forma de jornalismo (KEEN, 2009, p. 48).

Em seu livro "O Culto do amador", Keen critica ainda a abertura "exagerada" de alguns sites noticiosos a participação do leitor, em especial quan- 
do há a possibilidade de publicação de conteúdo sem a devida identificação de autoria, através do uso de apelidos ou pseudônimos. Com o crescimento das áreas destinadas a conteúdos gerados por leitores, Keen acredita ser necessário um controle cada vez maior por parte de editores e profissionais da área jornalística. Além disso, a exigência de um cadastro dos leitores se mostra importante à medida que oferece a possibilidade de conhecer melhor o colaborador e facilita na tomada de ações corretivas no caso de uma conduta inadequada como, por exemplo, no uso de termos comprovadamente ofensivos ou relatos sem compromisso com a realidade.

Num mundo com um número cada vez menor de editores ou revisores, profissionais, como saber no que ou em quem acreditar? Como grande parte do conteúdo gerado pelo usuário na internet é publicada anonimamente ou sob um pseudônimo, ninguém sabe quem é de fato o verdadeiro autor desse conteúdo autogerado (KEEN, 2009, p. 25).
Sendo ou não considerado jornalismo, o conteúdo produzido por usuários cada vez mais se consolida em uma realidade, e sua implementação por parte também dos sites noticiosos apresentase como um caminho sem volta. Nesse sentido, torna-se importante a discussão a respeito da possível necessidade de mecanismos de controle para a publicação desse tipo de conteúdo nos sites de grandes empresas noticiosas.

\section{O controle da informação: mecanismos de moderação}

Analisando alguns modelos de interação simples e limitada, como é o caso, por exemplo, das seções de comentários presentes em quase todos os sites de notícias, é comum a existência de conteúdos repletos de conceitos que podem ser considerados ofensivos e/ou preconceituosos. Os exemplos da figura são de comentários publicados em matérias do site www.oglobo.com.br, onde há a presença de filtros de conteúdo e ferramentas de denúncia de conteúdo ofensivo por parte de outros leitores.

Figura - Exemplos de comentários publicados em plataforma com moderação editorial - nov. 2010

\begin{tabular}{|c|c|c|c|c|}
\hline $\begin{array}{l}\text { Edissalopes } \\
16 / 11 / 2010-14 \text { h } 09 \mathrm{~m} \\
\text { Q HISTORIA MAL CONTADA.... } \\
\text { COM TANTO V.I.A.D.O NA PRAIA } \\
\text { POR CAUSA DA PARADA PQ IRIAM } \\
\text { ATIRAR JUSTAMENTE NESSA } \\
\text { UNICA CRIATURA?m? OU NÃO } \\
\text { TEM NADA A VER COM } \\
\text { HOMOFOBIA E ISSO TA SENDO } \\
\text { USADO (ASSIM COMO FAZEM OS }\end{array}$ & \multicolumn{3}{|c|}{$\begin{array}{l}\text { KriticomM } \\
16 / 11 / 2010 \text { - 13h } 51 \mathrm{~m} \\
\text { Eliane de Carvalho, } \\
\text { nunca vi tanta asneira num post só. } \\
\text { Se educar seu filho num caminho reto e mostrando o que é certo e errado e } \\
\text { praticando isso, nunca filho de ninguem vai ter curiosidade por essa anomalia } \\
\text { moral. } \\
\text { Não é só porque vc e sua orda praticam essa pederasttia, que os outro vão } \\
\text { também. }\end{array}$} & $\begin{array}{l}\text { + EX MINISTRA JAZ AQUI! } \\
\text { Causa mortis: CANCER } \\
\text { + EX MINISTRA PRESIDENTA } \\
\text { TAMBÉM JAZ AQUI ! CaUSa } \\
\text { mortis : CANCER E CANANALHICE ! }\end{array}$ \\
\hline $\begin{array}{l}\text { NEGROS COM A HISTORIA DE } \\
\text { RACISMO) COMO DESCULPA OU O } \\
\text { CARA ARRUMOU ALGUMA } \\
\text { CONFUSÃO E REVIDARAM COM } \\
\text { TIRO. }\end{array}$ & $\begin{array}{l}\text { AKmelo } \\
16 / 11 / 2010-13 \mathrm{~h} 46 \mathrm{~m} \\
\text { Morte aos sa.fa,dos!l! } \\
\text { Este comentário é ofensivo ou } \\
\text { inapropriado? Denuncie aqui }\end{array}$ & \multicolumn{3}{|c|}{$\begin{array}{l}\text { Jonas Rimmer } \\
\text { 16/11/2010 - } 14 \text { h } 08 \mathrm{~m} \\
\text { Eliane, você surtou. Menos de } 2 \% \text { da população é portadora de homossexualismo } \\
\text { de fundo neurológico. Nāo existe chance de "todo jovem daqui a uns ter } \\
\text { curiosidade". O mal dos gays é achar que os héteros, mesmo sem demonstrar, } \\
\text { podem sentir uma "quedinha" por eles. }\end{array}$} \\
\hline \multirow{2}{*}{\multicolumn{3}{|c|}{$\begin{array}{l}\text { 666Dark } \\
\text { 16/11/2010 - } 13 \mathrm{~h} 41 \mathrm{~m} \\
0 \text { grupo Arco-Ires divulgou uma nota pedindo enégicas providências na apuração } \\
\text { do caso, porque não se conforma na ma pontaria do cara, todo mundo sabe que } \\
\text { gays levam ferros nos ânus e esse cara que atirou errou por muito!!! } \\
\text { Heheheheheheee... }\end{array}$}} & \multicolumn{2}{|l|}{$\begin{array}{l}\text { pilib } \\
16 / 11 / 2010 \cdot 14 \mathrm{~h} 17 \mathrm{~m}\end{array}$} \\
\hline & & & \multicolumn{2}{|l|}{$\begin{array}{l}\text { Homofóbios PORCOS! } \\
\text { é isso que se vê aqui. }\end{array}$} \\
\hline \multicolumn{3}{|l|}{$\begin{array}{l}\text { 666Dark } \\
16 / 11 / 2010-13 \mathrm{~h} 50 \mathrm{~m}\end{array}$} & \multicolumn{2}{|c|}{$\begin{array}{l}\text { Incentivadores de crimes fantasiados de moralistas. } \\
\text { São todos BAN-DI-DOS igual aos que atiraram no jovem desarmado. }\end{array}$} \\
\hline \multirow{2}{*}{\multicolumn{3}{|c|}{$\begin{array}{l}\text { Esse caso está parecendo ciumes de outro gay inconformado, deu um tirinho mal } \\
\text { dirigido no } b^{*} 0^{*} i^{*} 0^{*}\left({ }^{*} a \text {. }\right. \\
\text { Aí eles aproveitaram e deram uma de sabidos para conseguir algum, mas trocaram } \\
\text { a côr da farda. }\end{array}$}} & \multicolumn{2}{|l|}{ PORCOS COVARDES! } \\
\hline & & & \multirow{2}{*}{\multicolumn{2}{|c|}{$\begin{array}{l}\text { Capitao Nemo } \\
17 / 11 / 2010-15 \mathrm{~h} 47 \mathrm{~m} \\
\text { NAZI PTISTA é como, ladrão, prostituta e viciado em droga! } \\
\text { Nunca se regenaram! } \\
\text { Só dão "um tempo"... }\end{array}$}} \\
\hline \multicolumn{3}{|l|}{ Muiiiito suspeito!! } & & \\
\hline
\end{tabular}

Fonte: <http://www.oglobo.com.br>. 
Mesmo com todos os cuidados e medidas tomados, o que se observa nessas plataformas é que uma comunidade se torna extremamente difícil de ser vigiada ao permitir que um número excessivo de vozes se manifeste. Essa questão é tratada por Johnson (2003), partindo do princípio da existência de um "estágio de clímax" em uma comunidade, ou seja, um ponto onde a relação entre os indivíduos atinge um estágio ideal, a partir do qual o crescimento no número de indivíduos provocaria o declínio no funcionamento dessa relação. Segundo Johnson, uma comunidade com poucos indivíduos tende a não funcionar bem como coletivo, pois na medida em que essa comunidade cresce, as relações se consolidam até o "estágio de clímax" e, a partir, daí a continuidade do aumento no número de indivíduos faz com que essa comunidade saia do controle (2003). Em comunidades virtuais, como a dos sites noticiosos, onde o interesse dos leitores tende a rapidamente ultrapassar o "estágio de clímax" é de fundamental importância que exista algum tipo de controle da informação publicada (seja esse controle editorial ou exercido pelos próprios leitores do site). Do ponto de vista da ética, uma nova dificuldade que se impõe é a de estabelecer critérios para definir o que é ofensivo, o que é preconceituoso, e até que ponto uma opinião emitida pelo leitor, por mais contrária que seja à política do jornal, deve ser "censurada", na medida em que esta opinião, a priori, representaria o conceito de verdade na ótica daquele leitor específico.

Em seções como as de comentários, já está evidenciado e convencionado se tratar da opinião independente dos leitores, sem relação com a visão da empresa noticiosa. Ainda assim, a existência de filtros mostra que os jornais estão preocupados em encontrar mecanismos de controle para esse tipo de situação, partindo da constatação de que conteúdos ofensivos tendem a atrair menos pessoas interessadas em contribuir com informações verdadeiramente relevantes para o jornal.

A aplicação desse ideal de controle da informação se torna mais complicada em modelos de colaboração mais complexos, com conteúdo gerado coletivamente a partir de relatos individuais. Em modelos que buscam valorizar a participação de usuários, oferecendo a possibilidade do envio de matérias (como exemplos os sites brasileiros g1. globo.com, globoesporte.globo.com ou oglobo. com.br), ou apontando para a construção de uma base de dados que possibilite a geração de conteúdos verdadeiramente coletivos, a questão da confiabilidade da informação se torna ainda mais importante. Uma vez que o conteúdo enviado por colaboradores passa a ser utilizado não somente com o caráter ilustrativo e opinativo das sessões de comentários atuais, mas como uma nova fonte geradora de conteúdo com um grau de importância semelhante ao da matéria jornalística produzida por profissionais, ou ao menos como um conteúdo que agregue verdadeiramente valor ao conteúdo editorial do jornal, torna-se fundamental estabelecer um mecanismo que assegure a credibilidade e a veracidade das informações colaborativas.

Diante de uma possibilidade de geração de conteúdo e consequente publicação aberta a qualquer indivíduo, Keen (2009) defende a ideia de se reforçar o papel exercido pelo jornalista profissional, dando a ele o papel de avaliar toda e qualquer colaboração pretensamente noticiosa enviada por amadores e reescrevê-la de maneira a sustentar os padrões de imparcialidade e objetividade esperados pelos leitores.

Entretanto, por maior que seja a empresa jornalística, é evidente a impossibilidade de uma equipe de editores capaz de validar todas as informações enviadas pelos leitores, à medida que o número de leitores tende a aumentar proporcionalmente ao sucesso do modelo de colaboração utilizado pelo site noticioso.

Dessa maneira, pode-se apontar que a comunicação colaborativa traz novos paradigmas para o processo de edição e filtragem da informação. Antes, existiam "portões" de informação controlados por jornalistas em redações que eram responsáveis por selecionar quais fatos seriam publicados de acordo com critérios de "noticiabilidade" e em função da limitação de espaço oferecida pelos meios tradicionais. Em um artigo que analisa a produção colaborativa na Internet, 
Barros (2007) explica que esse processo seletivo é conhecido como gatekeeping, pois remete à ideia do guarda (keeper) de um portão (gate) que é responsável pela decisão dos conteúdos veiculados pela mídia.

No novo contexto da Web, Bruns (2003) propõe uma recontextualização dessa teoria, e utiliza o termo gatewatching para denominar os processos de filtragem que existem na Internet. Nesse novo processo, o guarda é substituído por um vigia, o usuário, que tem o poder de decisão sobre aquilo que tem mais ou menos importância, está certo ou errado. Träsel (2007) aborda a questão, apontando a importância desse processo de filtragem e a possibilidade de que tudo fique a cargo do próprio leitor/usuário:

[...] as características específicas da Internet geram uma profusão de informação que exige algum tipo de mediação para fazer sentido. Esta mediação, está claro, pode ser feita por jornalistas profissionais, papel que de todo modo estes sempre desempenharam nos meios tradicionais. As redes de computadores, porém, permitem que o próprio público faça esse trabalho, na medida em que facilitam a cooperação (TRÄSEL, 2007, p. 52).

Nesse sentido, a meta-moderação (JOHNSON, 2003; KEEN, 2009) seria uma maneira de se garantir a qualidade e a autenticidade das notícias enviadas pelos cidadãos-repórteres. Nesse sistema, os próprios usuários do site são responsáveis em controlar o fluxo de informações fazendo correções ou alertas sobre conteúdos inapropriados. Primo e Träsel exemplificam:

Uma matéria polêmica, tendenciosa ou mesmo falsa pode receber milhares de mensagens de leitores consertando ou retificando os dados recém publicados. E com a possibilidade de escrita hipertextual, as respostas no fórum podem trazer links para outras fontes na Web, que aperfeiçoam o tema em discussão. Mas o que diferencia o webjornalismo participativo é a descentralização do processo de correção de informações erradas (2006, p. 45).

Entretanto, na visão de Keen, a meta-moderação, da maneira como é utilizada pelos sites de notícias, ainda é um sistema suscetível a falhas e até mesmo manipulações. Para ele, por trás de uma falsa ideia de democracia, a atitude de dar poder de editoração ao usuário está tendo um efeito contrário, gerando uma mídia ainda mais corrupta e antiética:

Por mais que se proclamem mais democráticos e honestos, esses sites de notícias sociais supostamente não editados estão de fato criando uma mídia mais oligárquica e corrupta. Sites de notícias sociais [...] estão sendo manipulados pelos chamados "influenciadores" - pessoas que elevam artificialmente a classificação de certas notícias nesses mecanismos de recomendação [...] O mais perturbador de tudo com relação aos sites de notícias sociais é que muitos influenciadores estão burlando os mecanismos para promover seus próprios interesses. Segundo o relato do Wall Street Journal, algumas companhias de marketing estão agora vendendo "exibição na primeira página”. Outras pagam abertamente influenciadores para promover notícias (KEEN, 2009, p. 92).

Johnson também apresenta uma reflexão a respeito do real caráter democrático da meta-moderação, e dos perigos de que a individualidade seja sobrepujada pela avaliação da maioria.

Há algum perigo em ir para um mundo onde toda a mídia responde diretamente ao feedback do usuário? [...] A coletividade decide o que é qualidade e o que é porcaria, para usar a linguagem de Rob Malda. Talvez, então, o perigo esteja no excesso de pensamento de grupo. Malda projetou seu sistema para avaliar contribuições com base no leitor médio do Slashdot. É totalmente possível que as regras de Malda tenham criado uma tirania da maioria em Slashdot. Mensagens que coincidem com o usuário "médio" tem mais possibilidade de chegar ao topo, enquanto as que expressam um ponto de vista da minoria podem ser rebaixadas no sistema (JOHNSON, 2003, p. 125).

A partir dos argumentos de defesa e de crítica, fica claro que não existe uma unanimidade quanto ao melhor modelo de controle para a crescente quantidade de informações decorrentes da colaboração de usuários em sites noticiosos.

Além da moderação realizada por editores profissionais e da meta-moderação, realizada pelos próprios usuários, existem ainda outras maneiras de lidar com o controle da informação gerada por usuários. Um possível caminho é o avanço nos processos de automatização da moderação, baseada em programas de computador capazes de "aprender" a moderar a informação, a partir 
de algoritmos de aprendizado supervisionado o chamado supervised learning (LI; WU, 2010). Segundo os autores, no contexto do aprendizado supervisionado, a moderação realizada de maneira tradicional é analisada por software em busca de padrões de comportamento, e os algoritmos são capazes de aprender a filtrar o conteúdo por conta própria, automatizando o processo com um alto índice de acerto. Processos de moderação automatizada vão desde a simples filtragem de palavras inapropriadas (blacklists com termos que devem ser excluídos, como por exemplo, palavrões) até software capaz de aprender a identificar se um conteúdo deve ser publicado ou não em função de uma "análise de sentimento" deste conteúdo. A partir da análise de uma moderação por parte de um editor real, é possível encontrar padrões que possibilitam ao software identificar se um conteúdo é "positivo" mesmo com o uso de palavras que, individualmente, seriam consideradas inapropriadas, ou um conteúdo sem nenhuma palavra imprópria pode ser considerado "negativo" por ser identificado como algo irônico ou falso. Entretanto, esse tipo de análise ainda é profundamente discutido por apresentar margens de erro consideradas excessiva e por ser baseada em conceitos abstratos e que ainda exigiriam a presença de um moderador real verificando o processo (LI; WU, 2010).

Seja qual for o mecanismo utilizado, é consenso entre os grandes portais de notícias a necessidade de filtros de informação como forma de manter a oferta de conteúdo relevante e de credibilidade, seja ele produzido por profissionais ou por amadores.

\section{Copyright e direitos autorais do conteúdo colaborativo}

Um dos principais pontos de discussão na questão do conteúdo enviado via colaboração de leitores é a propriedade intelectual. Seções de jornalismo colaborativo contam, exclusivamente, com textos e materiais produzidos por terceiros, e compartilhados por iniciativa própria. Dessa forma, o sistema de propriedade intelectual, na forma de copyright, como era feito até então, parece não se adequar a realidade da Internet. As novas tecnologias contribuem, portanto, para que se questionem os fundamentos da forma mercadológica e da lógica da intermediação capitalista que até então protegiam o produto imaterial, os saberes e a informação. Essa pode ser considerada uma característica inerente à própria Internet. Para Castells, a história da Internet reforça a ideia de que a cooperação e a liberdade de informação podem ser mais propícias à inovação do que à competição e os direitos de propriedade (2001 p. 13).

Para Lemos, as próprias ideias de autoria e propriedade intelectual se perdem nesse novo modelo cultural e precisam ser rediscutidas:

As noções de autor e de propriedade intelectual surgem com o capitalismo e a imprensa a partir do século XVIII. Até então, culturas primitivas e orais, assim como a sociedade medieval, não possuíam uma idéia de autor nem de propriedade de bens simbólicos. A modernidade industrial vai trazer essa ideia romântica de um autor iluminado e dono de sua criação. Ela será usada para controlar a circulação de bem tangíveis e intangíveis, onde o autor cede o seu direito aos editores em troca de pagamento de royalties. Esse sistema esteve mais ou menos estável até o surgimento do pós-modernismo (meados do século XX) onde o artista passa a buscar a quebra de fronteiras e usar trabalhos de outros artistas em processos de recombinação. A arte entra em crise e junto com ela a noção de obra, autor, autoria, propriedade. $\mathrm{Na}$ crise da criação pós-moderna, só é possível apropriações sob o signo da recriação. Não há mais autor, original e obra, apenas processos abertos, coletivos e livres (LEMOS, 2009, p. 57).

Seguindo esses novos paradigmas, vêm surgindo novos sistemas de regulação da informação. Um deles é o copyleft, trocadilho que substitui o right (direita ou direito, em inglês) de copyright por left (esquerda ou a conjugação no passado do verbo leave, deixar). Dessa forma, copyleft pode ser entendido como algo próximo de "cópia autorizada". Sobre essa temática, Lima e Santini afirmam:

O copyleft é uma relação contratual construída a partir da legislação do copyright, normalmente da mesma forma que qualquer licença tradicional de proteção dos direitos autorais entre o autor e quem o publica. São algumas cláusulas deste contrato que faz o copyleft diferente e merecedor de um nome especial (LIMA, SANTINI, 2008, p. 5). 
Nesse sistema, os produtores mantêm o direito autoral 'moral' sobre seus produtos, mas todos podem copiar e usar livremente as informações produzidas. Dessa forma os criadores de conteúdos podem proteger os direitos do seu trabalho enquanto o disseminam amplamente, criando um ambiente de cultura livre, onde seus trabalhos circulam com liberdade.

Outra forma de regulação do uso de sistemas e conteúdo é o Creative Commons (CC), que tem por finalidade desenvolver instrumentos concretos, licenças, que possam ser usados por qualquer pessoa ou organização, para que seus trabalhos venham a ser disponibilizados para uso, cópia, disseminação e recriação. Essas licenças são instrumentos legais que permitem aos autores estabelecer os termos sob os quais querem compartilhar suas obras, mantendo o seu direito moral de reconhecimento como criadores e proibindo, por exemplo, o uso comercial.

Segundo Lessig (2007), é preciso fazer com que o novo sistema de criatividade coexista com o sistema de propriedade intelectual já existente. Para ele o objetivo do CC é encontrar uma forma simples de marcar o conteúdo com o limite de liberdade intencionado por seus autores, para que, dessa forma, o público que se interesse por aquele produto saiba o que é permito ou não fazer a partir dele.

O Creative Commons cria, portanto, a opção de um meio termo legal entre "todos os direitos reservados" dos contratos de direito autorais tradicionais e o domínio comum, ajudando o autor a manter seu direito autoral ao mesmo tempo em que permite certos usos de sua obra. Seria um licenciamento com "alguns direitos reservados". O Creative Commons se posiciona como moderador das autorizações de uso e coloca à disposição dos autores - em sua página da Internet ${ }^{1}$ - formulários que permitem escolher as características de distribuição das suas obras, as licenças que podem ser incorporadas aos sites e que regulam os usos dessa obra. Uma vez preenchidos estes formulários, o sistema gera a licença em três for- matos: resumo de uso autorizado, texto legal e uma versão digital com metadados que se pode usar para facilitar o trabalho dos "buscadores" na Internet.

No caso dos sites noticiosos e grandes portais de jornalismo, normalmente o envio de conteúdo é atrelado a concordância por parte do colaborador com os "termos de uso" propostos pela empresa jornalística. Os termos de uso variam de site para site, mas, de forma geral, o objetivo é garantir que a responsabilidade pela veracidade do conteúdo enviado é do colaborador (protegendo a empresa de possíveis medidas legais), e que o conteúdo pode ser usado livremente pelo jornal na composição de seu conteúdo noticioso. Noci e Palacios (2008, p. 247) ressaltam a preocupação dos sites com a questão ética envolvida no processo colaborativo:

\footnotetext{
Há um interesse dos jornais online em expandir a participação e a interação com o leitor, porém a grande maioria mantém o controle da maior parte das fases da produção informativa nas mãos de jornalistas e editores. Há também a preocupação com a questão legal envolvida nisso.
}

Dessa maneira, a concordância com os termos de uso apresentados tiram do site noticioso a responsabilidade legal por qualquer problema relacionado ao conteúdo recebido via colaboração, no caso de sua publicação.

\section{Ética no cenário atual da colaboração: conclusões e próximos passos}

Em sua discordância ao que considera uma supervalorização do conteúdo produzido por amadores, Keen apresenta argumentos identificados no campo da economia, cujos dados estatísticos indicam um real declínio das empresas noticiosas nos últimos anos, processo que acompanhou diretamente a evolução da Internet e dos sites de notícias gratuitos, alimentados por amadores.

O mais grave de tudo é que as próprias instituições tradicionais que ajudaram a promover e criar nossas notícias, nossa música, nossa literatura, nossos programas

${ }^{1}<$ http://creativecommons.org/>. 
de televisão e nossos filmes estão igualmente sob ataque. Jornais e revistas de notícias, uma das fontes mais confiáveis de informação sobre o mundo em que vivemos, estão em dificuldades, graças a proliferação de blogs e sites gratuitos [...] No primeiro trimestre de 2006, os lucros despencaram de maneira impressionante em todas as principais empresas jornalísticas - caíram 69\% na New York Times Company, 28\% na Tribune Company e $11 \%$ na Gannett, a maior empresa jornalística dos Estados Unidos. A circulação também caiu. O público leitor do San Francisco Chronicle, ironicamente um dos principais jornais do Vale do Silício, caiu estonteantes $16 \%$ apenas no segundo e terceiro trimestres de 2005 . E em 2007, Time, Inc., dispensou quase 300 pessoas, sobretudo do corpo de redatores, de revistas como Time, People e Sports Illustrated (KEEN, 2009, p. 13).

Dessa forma, a utilização crescente de conteúdo colaborativo nos sites de grandes jornais pode ser encarada como uma forma de adequação a essa nova realidade. Tal processo, entretanto, deve ser cercado de cuidados, na tentativa de evitar que a entrada desse novo elemento ao jornalismo tradicional - ao invés de se converter em um acréscimo de conteúdo - acarrete na perda de qualidade e de identidade do jornal. O limiar entre a publicação de conteúdo amador e o ponto aonde esse conteúdo de alguma forma pode suplantar o papel do jornalismo profissional ou comprometer o modelo editorial do jornal constitui-se, sem dúvida, em um grande desafio enfrentado pelas empresas jornalísticas nos dias de hoje.

Apesar da constatação apontada por Keen de que a mudança paradigmática que atingiu o jornalismo nos últimos anos afetou diretamente os lucros e até certo ponto coloca em risco o futuro de empresas tradicionais do ramo, ainda é cedo para aferir se esse será um processo definitivo ou se é uma etapa transitória, de adequação a uma nova realidade.

A própria importância dada pelos grandes sites de notícias ao jornalismo colaborativo, e os espaços cada vez maiores destinados a esse tipo de jornalismo não deixam de ser uma forma encontrada pelas empresas de se adaptar as mudanças ocorridas nos últimos anos. Ao invés de encarar o leitor como um "jornalista amador", ou como um concorrente, os jornais estão partindo justamente para a integração, na busca de encontrar o ponto exato de união entre o que há de melhor em ambos os lados. Uma vez que a Internet acendeu no leitor a possibilidade de fazer parte do processo comunicacional como emissor da informação, espera-se que isso seja desenvolvido, estimulado e aproveitado da melhor forma possível pelos grandes jornais. O sucesso dos sites de notícias colaborativas e o declínio de algumas das principais empresas jornalísticas mostra que esse é um fato que não pode ser ignorado.

Ao mesmo tempo, se de um lado verifica-se um entusiasmo com a ascensão do modelo de jornalismo colaborativo, de outro se aponta os perigos de uma euforia exagerada na abertura das grandes empresas de notícias à participação de leitores na geração de conteúdo. De um lado, estão os que valorizam o dinamismo e o caráter de realidade, amplificados pelos modelos de jornalismo colaborativo; de outro lado, questiona-se a validade desse tipo de jornalismo. Para ambos, há o objetivo comum de buscar o modelo ideal, que possa conciliar a coexistência dos dois modelos, aliando a curadoria editorial do jornalismo tradicional à polifonia do jornalismo colaborativo.

O próprio Andrew Keen, um dos maiores críticos a forma como a colaboração de usuários vem sendo implementada nos sites noticiosos, indica acreditar um modelo que possibilidade essa integração com algum sucesso, citando o exemplo do "The Guardian Unlimited":

Também muitos jornais e revistas tradicionais estão respondendo aos desafios que enfrentam casando novas mídias com conteúdo tradicional sem comprometerem padrões editoriais ou de qualidade. Uma dessas instituições é o jornal britânico de centro-esquerda The Guardian, que conseguiu passar a exibir parte de seu conteúdo online ao mesmo tempo que mantém um padrão de alta qualidade na coleta e na transmissão de notícias. Sua versão online, The Guardian Unlimited, fez um trabalho tão brilhante de integração das tradições altamente confiáveis do jornal com a democracia interativa do mundo da Web 2.0, que agora se gaba de ter mais leitores online nos EUA do que jornais nacionais de primeira linha como o Los Angeles Times. Sem dúvida, o Guardian Unlimited tem quadros de mensagens anônimos repletos de opiniões desinformadas e não verificadas geradas por leitores. Mas, ao contrário do que acontece em muitas edições online em que blogs de leitores e anúncios pagos são indistinguíveis de artigos 
verdadeiros, no Guardian Unlimited a divisão entre reportagem profissional e opinião amadora é claramente delineada (KEEN, 2009, p. 177).

Em "A Ideologia alemã", Karl Marx indica um mundo ideal pós-capitalismo, onde todos podem "caçar de manhã, pescar de tarde, criar gado ao entardecer e criticar após o jantar" (apud KEEN, 2009, p. 40). Para Keen, não é possível imaginar esse mundo onde todos possam ser bons em caçar, pescar, criar gado e criticar ao mesmo tempo. "Num mundo em que todos nós somos amadores, não há especialistas” (2009, p. 40).

Entretanto, indo um pouco além, deve-se questionar até que ponto é isso que se espera da colaboração de leitores. O modelo vigente, que visa dar ao leitor o papel (ou a responsabilidade) de ser um “jornalista”, seria a única forma de utilizar conteúdos de amadores em sites de noticias? Talvez o problema não esteja só na abertura de espaço a participação de amadores, mas sim em exigir deles que o material produzido deva, necessariamente, seguir regras e padrões de ética que não são inerentes à formação individual de cada um deles. A solução pode estar além do que propõe Keen no exemplo do "Guardian Unlimited". Estabelecer uma divisão clara entre o conteúdo do jornal e o conteúdo enviado por leitores sem dúvida é uma saída, mas um próximo passo deveria acontecer no caminho da integração desses dois conteúdos. Talvez não seja preciso criar separações para diferenciar uma matéria jornalística do conteúdo enviado por "amadores" no momento em que os próprios jornais deixem de exigir que o usuário adapte seu relato a uma padronização jornalística imposta de cima para baixo.

O que é mais relevante na participação de usuários, além da multiplicidade de pontos de vista e de discursos, é justamente o conteúdo puro, o relato de um fato visto pela ótica de quem se considera em condições de acrescentar informação relevante a um determinado tema (seja por ter presenciado um acontecimento, seja por quaisquer outras razões), e não a forma sob a qual esse relato é produzido e enviado. Exigir do usuário o mesmo apuro jornalístico ou a mesma técnica de um jornalista profissional é injusto e, nesse sen- tido, pode realmente ferir a ética jornalística ao nivelar profissionais e amadores em uma mesma categoria. É necessário que a euforia com as possibilidades surgidas com o jornalismo colaborativo não se confunda com uma desvalorização do que é produzido pela mídia convencional, conforme alerta Keen:

Não entremos portanto para a história como aquela famigerada geração que, embriagada pelo ideal de democratização, matou a mídia convencional [...] Em vez disso, usemos a tecnologia de uma maneira que estimule a inovação, a comunicação aberta e o progresso, preservando ao mesmo tempo padrões profissionais de verdade, decência e criatividade (KEEN, 2009, p. 191).

A solução ideal, ainda não encontrada, passa necessariamente por esse questionamento a respeito da forma com que a participação do leitor deve ser aproveitada pelos jornais e oferecida para o público geral. Entre simplesmente ignorar o crescimento do jornalismo colaborativo; segmentar as colaborações a uma seção isolada (como um jornal dentro do jornal); ou misturar conteúdo editorial e colaborativo de uma forma que confunda o leitor e prejudique a credibilidade do jornal, talvez seja possível vislumbrar um modelo que integre verdadeiramente o conteúdo do profissional com o conteúdo do amador, transmitindo ao leitor final uma versão cada vez mais rica e completa dos fatos. De toda forma, essa é uma discussão ainda inconclusa e sujeita a experimentações por parte das grandes organizações jornalísticas, de maneira a buscar a melhor solução para integração do conteúdo colaborativo ao conteúdo editorial, esbarrando em muitos momentos com a questão ética que permeia a prática jornalística em toda sua história, sendo sem dúvida um dos grandes desafios que as empresas jornalísticas terão que enfrentar nos próximos anos. 


\section{Referências}

BARBEIRO, H.; LIMA, P. R. Manual de Telejornalismo: os segredos da notícia em TV. Rio de Janeiro: Campus, 2002.

BARROS, F. Produção e edição colaborativa na Internet: o caso overmundo. Ciberlegenda, v. 9, n. 19, Out. 2007. Disponível em: <http://www.uff.br/ciberlegenda/ edout2007.html>. Acesso em: 11 jul. 2014.

BRAMBILLA, A. M. Jornalismo open source: discussão e experimentação do OhmyNews International. Porto Alegre, UFRS, 2006.

BRUNS, A. Gatewatching, not gatekeeping: collaborative online news. Media International Austrália, n. 107, p. 31-44, 2003. Disponível em: <http://eprints.qut.edu. au/189>. Acesso em: 11 jul. 2014.

CASTELLS, M. A Galáxia da Internet: reflexões sobre a Internet, os negócios e a sociedade. Rio de Janeiro: Jorge Zahar Editor, 2001.

DALMONTE, E. F. Pensar o Discurso no webjornalismo: temporalidade, paratexto e comunidades de experiência. Salvador: EDUFBA, 2009.

GARCIA, L. (org.). Manual de redação e estilo de “O Globo". São Paulo: Globo, 1992.

GILLMOR, D. We the Media: grassroots journalism by the people, for the people. O'Reilly, 2004.

JOHNSON, S. Emergência: a vida integrada de formigas, cérebros, cidades e softwares. Rio de Janeiro, Jorge Zahar, 2003.

KEEN, A. O Culto do amador: como MySpace, Youtube e a pirataria digital estão destruindo nossa economia, cultura e valores. Rio de Janeiro, Jorge Zahar, 2009.

KOVACH, B.; ROSENTIEL, T. Os elementos do Jornalismo: o que os jornalistas devem saber e o público exigir. São Paulo: Geração Editorial, 2003.

LEMOS, A. Ciber-cultura-remix. São Paulo, Itaú Cultural, 2005. Disponível em:

<http://www.facom.ufba.br/ciberpesquisa/andrelemos/ remix.pdf $>$. Acesso em: 11 jul. 2014.

LESSIG, L. The vision for the Creative Commons: what are we and where are we headed? Free Culture. In: FITZGERALD, B. (ed.) Open content licensing: cultivating the Creative Commons. Sydney: Sydney University Press, 2007. Disponível em <http://eprints. qut.edu.au/archive/00006677/01/6677.pdf > . Acesso em: 11 jul. 2014.
LI, N.; WU, D. D. Using text mining and sentiment analysis for online forums hotspot detection and forecast, 2010. Disponível em: <http://www.cs.ucsb. edu/ nanli/publications/N.Li_2010_DSS.pdf >. Acesso em: 11 jul. 2014.

NOCI, J. D.; PALACIOS, M. Metodologia para o estudo dos cibermeios: estado da arte \& perspectivas. Salvador, EDUFBA, 2008.

PRIMO, A. TRASËL, M. R. Webjornalismo participativo e a produção aberta de notícias. Contracampo, n. 14, p. 37-56, 2006. Disponível em: <http://www.uff.br/ contracampo/index.php/revista/article/view/512/355>. Acesso em: 11 jul. 2014.

TRÄSEL, M. R. A pluralização no webjornalismo participativo: uma análise das intervenções no Wikinews e no Kuro5hin. 2007. 271 f. Dissertação (Mestrado em Comunicação e Informação) Universidade Federal do Rio Grande do Sul, Porto Alegre, 2007. Disponível em: <http://www.ufrgs.br/ limc/PDFs/wiki_kuro.pdf >. Acesso em: 11 jul. 2014. 
Ethics, control and regulation of information in collaborative web journalism

\section{Abstract}

Introduction: The article discusses the ethical issue on the Internet, with a focus on collaboration of readers in news sites. The analysis covers the impact of the inclusion of collaborative content in the journalistic context, and presents questions about the relevance of this type of content as well as ways to integrate it with conventional news content. Method: Bibliographical study with a survey of references on the issue of collaboration readers in journalism sites on the impact of the inclusion of these collaborative practices for conventional journalism, and the possibilities of control and moderation of information sent by readers in order to validate their veracity. Results: Theoretical frameworks were found pointing to the advantages and disadvantages of using collaborative information on news sites as well as different mechanisms for integration and control of information, among them the pre-moderation, moderation and meta-moderation taken by automatic algorithms intelligence artificial. Conclusions: The ideal solution, not yet found, necessarily requires such questioning about the way in which the participation of the reader must be seized by newspapers and offered to the general public. This is a discussion that touches on many occasions with the ethical issue that pervades the journalistic practice throughout its history, and is arguably one of the greatest challenges that newspaper companies will face in the coming years.

\section{Keywords}

Collaboration in social networks. Web journalism. Information moderation. Ethics in Journalism.
Recebido em 25 maio 2014

Aceito em 1 julho 2014

\section{Sobre os autores:}

\section{Augusto de Freitas Lohmann}

Bacharel em Radialismo e em Jornalismo - ECO/UFRJ, Mestre em Design - ESDI/UERJ, Doutorando em Design UERJ. Arquiteto de Informação Sênior - Infoglobo. augustolohmann@gmail.com

\section{André Soares Monat}

Bacharel em Engenharia de Infra Estrutura Aeronáutica ITA, Engenharia de Sistemas e Computação - UFRJ, Doutor em Engenharia de Sistemas e Computação - UEA/Inglaterra. Estágio Pós-Doutoral - BUW/Alemanha. andresmonat@yahoo.com.br

Como citar este artigo:

LOHMANN, A. de F.; MONAT, A. S. Questão ética, controle e regulamentação da informação no webjornalismo colaborativo. Atoz: novas práticas em informação e conhecimento, Curitiba, v. 3, n. 1, p. 24-37, jan./jun. 2014. Disponivel em: <http://www.atoz.ufpr.br>. Acesso em: 